Article

\title{
Swedish Government and Country Image during the International Media Coverage of the Coronavirus Pandemic Strategy: From Bold to Pariah
}

\author{
Greg Simons 1,2,3 \\ 1 Institute for Russian and Eurasian Studies (IRES), Uppsala University, 75320 Uppsala, Sweden; \\ greg.simons@ires.uu.se \\ 2 Department of Communication Sciences, Turiba University, LV-1058 Riga, Latvia \\ 3 Ural Institute of Humanities, Ural Federal University, 620002 Yekaterinburg, Russia
}

Received: 28 September 2020; Accepted: 9 November 2020; Published: 12 November 2020

\begin{abstract}
The Coronavirus pandemic has caused a great deal of disruption and fear for countries and peoples around the globe. It has spread in a seemingly unstoppable manner, which has created a global crisis in terms of strategies to mitigate its effects, and how these strategies are communicated is vital to the credibility and legitimacy of those relevant actors. This paper examines and analyses how the Swedish government attempted to frame its pandemic strategy in the international mass media as a successful example of the 'Swedish model'. Initially, this was successful and those frames seemed to be accepted; however, this soon changed and instead of serving as an example to emulate it became a model to avoid. Using hegemony theory and indexing theory, this paper attempts to explain how and why this change occurred. The change in the coverage becomes apparent as the Swedish government's coronavirus policy and strategy of Sweden begins to increasingly diverge from the global orthodoxy of other countries, including the United Kingdom. Therefore, the politics of crisis management among the political elite begin to diverge and the politics of crisis management creates a more hostile and critical environment.
\end{abstract}

Keywords: Sweden; country image; crisis; coronavirus; index theory; hegemony theory

\section{Introduction}

Crises and the officially communicated response to them can make or break the image of key actors and even countries (Porfiriev and Simons 2012). Therefore, a crisis situation, even if it is usually perceived as being a problematic situation that threatens values, brings uncertainty, and is time critical, it does actually present other actors with an opportunity (Boin et al. 2005). The current Coronavirus pandemic that has struck and crippled many countries around the globe is a living contemporary example of this situation. There is already a growing literature on different aspects of the effects of the virus, but at this stage there is very little on how governments have tried to capitalize from it through communicating to global audiences.

It is the intention of this present article to track sharp changes in how international mass media cover an international crisis event (using Sweden as an example), i.e., something that is very newsworthy. During the Coronavirus pandemic, many countries, within a very crowded marketplace of ideas and messages, sought to communicate to the international audience the efficacy of their strategy and its legitimacy in comparison to the other approaches. Country size or hard power matters less than the power of their communication strategy and its ability to resonate and seize public attention. In this instance, a relatively minor global actor on the international stage, Sweden, attempted to frame its Coronavirus strategy in a positive light through international media outlets. This was initially 
successful and the 'Swedish model' gained a lot of positive attention, but then this frame changed to a much more negative one, interpreted by international mass media in a way that differed from the official Swedish government frame. This article begins by addressing the theoretical and conceptual aspects of crisis communication (including the informational and political dimensions) and the framing of foreign policy in mass media news production. The focus then switches to an overview of how the Swedish government had attempted to frame Sweden and the Swedish model in the global arena. How different world governments approached communicating the priorities, values, and strategies in their attempts at mitigating the effects of the Coronavirus is briefly raised in the next section in order to give context to the Swedish approach. The section following that concerns the method and approach used in this article. The Swedish government's attempts to frame the 'Swedish model' in their Coronavirus strategy in the international media and audiences is tracked and identified in official information releases. Exactly how these frames were received in the international media, focusing on two English language mainstream mass media outlets, is identified and analyzed, along with the rapid descent from a role model to emulate to a pariah to avoid.

\section{Crisis Communication}

Previous research has shown that there are both negative and positive uses of a crisis within the practice of international relations by actors (Simons and Kukartseva 2019). A crisis is conceived as an extra-ordinary event that breaks the normal routine and functioning of society (Boin et al. 2005). The term "crisis" is often invoked, but to what exactly is meant is not always clearly defined. A crisis can be defined as being present when three simultaneously present aspects occur: (1) A threat to values, which can involve a threat to human life, property, the economy, state integrity, and many other examples. (2) The element of uncertainty is present; the shortage of reliable information and the often rapid pace of events make the ability to predict what is going to happen next very difficult, which can raise the perceived levels of risk and threat being faced. (3) Time constraint is the final part of the puzzle, which is in connection to the simple calculation that the longer a crisis event continues, the more damage is done (Boin et al. 2005, pp. 2-4).

When a crisis situation transpires, the actor involved already has some form of communicative stance that is predetermined. This influences how an organization responds to a crisis with stakeholders. "Stances are placed on a continuum that has advocacy and accommodation as its anchor points. Advocacy involves an organization arguing for its interests, while accommodation involves the organization making concessions to the other parties. The stance an organization should take depends on the nature of various factors that make up the conflict situation" (Coombs 2014, p. 18). This situation demonstrates the relevance and role of information and communication in a crisis.

Joseph Scanlon noted in 1975, "every crisis is also a crisis of information [ ... ] Failure to control this crisis of information results in a failure to control the crisis, including its directly operational aspects" (Ogrizek and Guillery 1999, p. xi). The nature and scale of crisis communication is determined by the type of break-out event that marks the beginning of a particular crisis. Communication on and around a crisis may also be capable of prolonging a crisis or perhaps to trigger a relapse (Ogrizek and Guillery 1999, p. xii). The selection of focus and emphasis of value priority in any particular given society becomes readily apparent in the communication around a crisis. "These values tend to be broadly defined societal values such as security, safety, economic development, democratic legitimacy, environmental protection, and so on" (Nohrstedt 2011, p. 201). Value expectations are based upon notions and understandings of socially imposed rules or norms, interpretations of law and regulations, national and international mandates, and public expectations/opinion.

Crises can be selectively used to shape perceptions to enable greater leeway for an actor in a crisis event. "Crisis evaluations might contribute to institutionalize moral standards into formal rules or codes of conduct" (Nohrstedt 2011, p. 201). This is, in part, owed to a crisis event provoking a political call for action that is nominally and rhetorically meant to resolve the crisis at hand. Within the context of a crisis and the communication flows that occur, new challenges for the management of an event are 
occurring. One of these is the technical change that has shortened the news and information cycle to no more than a few minutes at the most, which gives very little time to officially and adequately respond. The second challenge is a massive proliferation of 'information outlets' that are radically altered and have broadened the assumed role of media in a crisis. "As a result, the new reality repeatedly challenges, then threatens, political and institutional power. It also distorts the credibility of leaderships and those that serve them" (Gowing 2009, p. 10). This requires a carefully considered approach to framing and communicating official policy through mass media to global publics.

\section{Framing Foreign Policy in Mass Media}

An influence factor to be considered is the area of frame building that involves the framing of media input, which is made up of materials that political actors communicate to newsrooms in order to facilitate their work whilst simultaneously attempting to influence news production (Rodelo and Muniz 2019). There are two broad approaches to understanding the government-media nexus within foreign policy, hegemony (Scollon 2003; Lemon 2014; Kilgo and Harlow 2019), and indexing (Andersen 2017; Allen and Blinder 2018; Mulherin and Isakhan 2019). Both of these theoretical approaches see the media as being too subservient to the government. Although the use by some studies, such as Mulherin and Isakhan (2019), of indexing theory on media coverage of the 2014 Australian government decision to fight the Islamic State indicate that there are some rare occasions when press coverage goes beyond the constraints of the parameters of the political elite debate. Another study by Allen and Blinder (2018), on the coverage of the immigration issue in the United Kingdom, also hints at a semi-autonomous role of the media in this domestic issue area that is assisted by the bureaucratic procedure of the administrative mechanisms of the state.

Hegemony concerns the thesis that government officials keep the publicly available information within very narrow ideological boundaries, which makes any democratic deliberation and influence all but impossible. Although, at times, political leaders are in conflict with each other, in principle, elites tend to agree on critical points and this impedes independent information flows and creates a 'consistency' in the uniformity of the message. On the other hand, indexing concerns elite disagreement, where the media is the 'index' that reflect the elite debate rather closely. Media tend not to offer critical analysis of policy decisions unless actors inside the government have done so first. Governments and officials spin their messages to the media in the hope of gaining some political leverage. The media's political influence, therefore, is related to how they respond and their ability to frame these official messages (Entman 2004, p. 4). Kilgo and Harlow (2019, p. 524) note in their study that the "hierarchy of social struggle reflects the enforcement of deeper power structures and social forces that influence newsroom practices, behaviors, and coverage" that tend to reinforce the status quo power relations. Framing of the messages is key to providing a way to a certain path to viewing an issue.

Entman (2004, p. 5) defines framing as "selecting and highlighting some facets of events or issues, and making connections among them so as to promote a particular interpretation, evaluation, and/or solution". There are a number of basic functions that are performed by frames covering political events, issues, and actors: "defining effects or conditions as problematic; identifying causes; conveying a moral judgement; endorsing remedies or improvements" (Entman 2004, p. 5). This is important as people can learn a lot concerning politics from the mass media, Bolsen (2011, p. 143) argues that there are three major determinants that shape political news: world events, advocacy groups, and the government. Frames can perform at least two of these functions, where the objects of the frames are political events, issues, and actors. As noted by Entman (2004, p. 47), "the central goal of all the political maneuvering over news frames is simply to generate support or opposition to a political actor or policy". The information domain is an area of conflict and contestation for influence in the cognitive domain of the audience, where information dominance and control of the information flows shape public opinion and perception. 


\section{Framing and Communicating Sweden and the Swedish Model to Global Audiences}

Sevin (2017, pp. 109-10) argues that Sweden is a country that has garnered a prominent place in the eyes of the global publics despite its relatively remote location and small population. Nation branding measurement studies can rank Sweden among the top ten countries with the strongest brand perception. Its brand narrative is centered on 'low' ${ }^{1}$ international political issues such as climate change or gender equality. This is seen within the context of the cultural specifics of foreign policy of Nordic states and the attractions of "Nordicness" in addressing various crises and challenges of contemporary times (Brommesson 2018). Sweden was seen as the originator of this concept; it involved the idea and approach of utilizing Nordic progressivity as a means of achieving foreign policy goals through collaboration and attraction (Mouritzen 1995). The concept of Nordicness in Swedish foreign and security policy defines its role perceptions on the international stage, where three roles have been identified by Brommesson (2018): internationalist leader during the late Cold War; Europeanized follower after joining the European Union; and, currently, a Nordic balancer.

Sweden was also seen by some as the actor that abandoned the Nordic concept as its priorities changed as a result of Swedish national interests becoming aligned with the European Union and Swedish party polemics (Mouritzen 1995, p. 18). The roles of collaboration and achieving consensus in international relations issues form the cornerstone of the efforts in trying to export the Swedish Model globally. This is seen, for example, in the conceptual formulation and practice of the value-normative construction of feminist foreign policy from 2015 with the idea of solidarity transforming international relations, together with attempts to promote and publicize it on the global stage (Aggestam and Bergman-Rosamond 2016). Sundstrom and Elgström (2019, p. 1) hail "Sweden's role as a norm entrepreneur, challenging predominant normative frames by enhancing existing gender norms". This conceptual approach links to and demonstrates the influence of the Nordic model and its concept of international collaboration and cooperation.

This leads to some contradictions in Swedish defense and foreign policy. For example, on the one hand being critical of the US-led Iraq invasion in 2003 (Dimitrova and Strömbäck 2008) and armed conflict in general, and yet on the other hand the Swedish government is currently undermining the long-held central value of neutrality/non-alignment (Simons et al. 2019). Such contradictions are often overlooked or not recognized. This is, at least in part, owing to the Swedish political elite's cognitive perception of their messianic-like global role in spreading their knowledge and practice for the vision of the greater good.

Swedish exceptionalism is a key aspect in the projected national image to the global public and the assumption or belief in the superiority of the Swedish model when compared to other competing visions. This is framed within liberal and humanitarian values that influence the behavior in the approach to public diplomacy and international communications (Simons and Manoilo 2019). Mouritzen (1995, p. 9) remarked that "Sweden [ ... ] has possessed the self-confidence necessary to stand up and 'teach' the rest of the world what is forwards and backwards when it comes to societal development". The generally high profile, positive global image and recognition as a small country attempting to change international relations through its value-normative conceptual approach to foreign policy does not mean other countries and actors are prepared to follow Sweden, which is exemplified in results of attempting to spread the idea and practice of feminist foreign policy (Sundstrom and Elgström 2019, pp. 13-14). Other international actors hold other opinions and perceptions concerning the most appropriate policy strategy of addressing problematic issues that can diverge from the orthodoxy of the messianic Swedish foreign policy narratives.

1 Topics not directly related to the survival of the state, for example, social and economic issues. 


\section{Coronavirus and Government Approaches to Strategy}

This section shall include and briefly detail only a small selection of countries: the Nordic countries (based upon a quick comparison across the region where Sweden is located) and the United States and the United Kingdom (representing the two countries from where the mass media outlets have been selected). When observing how the different governments of the world approached their strategies in countering the Coronavirus pandemic from a crisis communication and crisis management point of view, a number of similarities and differences are clearly identified. There was a sense of urgency and uncertainty in approaching the crisis. However, the emphasis in terms of which value to prioritize differed, and two broad approaches competed for public attention and a sense of legitimacy - the value of the economy's health versus the public's health (IMF 2020; OECD 2020). This binary approach to problem description created binary approaches to solutions, such as lock-down versus the idea of 'herd immunity'. As such, the situation generated different calls to mobilization behind forms of politicized policy to address the crisis.

According to the International Monetary Fund's policy tracker (IMF 2020), countries from the Nordic region $^{2}$ (Denmark, Finland, Iceland, Norway, and Sweden) took different approaches to the pandemic crisis. Finland experienced its first confirmed COVID-19 case on the 29th of January 2020. On 16 March 2020 it invoked the Emergency Powers Act, which closed the borders and restricted domestic movements. Denmark also restricted domestic movements (closing all schools and universities and no gatherings of more than 10 people) and closed its international borders in March. The Icelandic government's pandemic approach involved the mass testing of the population for COVID-19, contact tracing, and quarantine. Norway attempted to mitigate the spread of the virus and stabilize the economy, which involved the closure of schools, universities, and businesses; mandatory quarantine after travel; social distancing measures; and the implementation of travel restrictions. Sweden implemented no restrictions on the movement of people domestically, although advised social distancing and moved teaching at secondary schools and tertiary education to distance learning (not kindergartens or primary schools), and there was no mass testing. The first Swedish COVID-19 case was confirmed on 31 January 2020. ${ }^{3}$ By 1 September 2020, $0.8 \%$ of Swedish residents had tested positive for the virus and $0.06 \%$ had died with or of the virus. The government policy focus was on mitigating, rather than stopping, the pandemic (Ludwigsson 2020). In the very short-term, Sweden suffered a higher infection and death rate than other Nordic countries (that employed lock-down) (Savage 2020), which drew a lot of international criticism.

This contrasted with the British government, which implemented a range of measures including travel restrictions; social distancing measures; closures of entertainment, hospitality, non-essential shops, and indoor premises; and increased testing. ${ }^{4}$ The U.S. ${ }^{5}$ has implemented a range of similar measures to the United Kingdom, including travel restrictions, social distancing, the declaration of states of emergency, closure of schools and non-essential businesses, and increased testing.

A clear use of values and norms were used, which is detailed by Nohrstedt (2011) as a means to define societal priorities and to seek legitimacy and approval. It is also a signal of social and political expectations based upon socially imposed rules and norms that is connected to the role of expectation management of public fear and anxiety during the chaotic and unpredictable environment of a major global crisis. Governments and state institutions are also well aware of Gowing's (2009) warning that this new reality challenges and then begins to threaten the political and institutional power.

2 A comparison of the different Nordic COVID-19 strategies can be found at the following link-https://nordiclifescience.org/ different-covid-19-strategies-in-the-nordic-countries/.

3 Please see Swedish Radio for coverage at https://sverigesradio.se/artikel/7398979.

4 For official British government communications on the Coronavirus strategy, please see https://www.gov.uk/government/ publications/our-plan-to-rebuild-the-uk-governments-covid-19-recovery-strategy.

5 For information on the COVID-19 from the US government please see https://www.usa.gov/coronavirus. 


\section{Research Questions}

There are two research questions for this paper that stem from the literature review:

1. Is it theoretically possible for a foreign government to maintain news frame hegemony in another country's print media during a crisis?

2. Does hegemony or indexing theory of government-state relations adequately explain and account for the rapid change in the international media framing of the Swedish government's COVID-19 strategy?

\section{Method and Approach}

The approaches to textual analysis shall include content analysis (quantifications of different elements in text), argumentation analysis (the structure of argumentation used), and the qualitative analysis of ideas in the content (with a focus on COVID-19 policy) (Boréus and Bergström 2017, pp. 7-9). The combination of these approaches is expected to yield results on the ontology (what exists) and epistemology (knowledge and how we 'know' things) of reactions to mass mediated textual depictions of the effects of official Swedish government communications to the global publics within the context of their strategy during the Coronavirus pandemic. The objects of study include power, people, policy, human security and freedom, public health, economic health, and so forth (Boréus and Bergström 2017, pp. 1-2). The mass media texts then contextualize the relationships according to perceived and projected power in the constructed social world order of mankind, such as justice and injustice, powerful and powerless, legitimate and illegitimate, worthy and unworthy.

The above-mentioned approach to media text analysis is conducted within the framework of Schutz on social phenomenology, which Fereday and Muir-Cochrane (2006, p. 81) notes "is a descriptive and interpretive theory of social action that explores subjective experience within the taken-for-granted, "common sense" world of the daily life of individuals". Schutz (1967) established a method for studying social interaction that involves two senses of understanding interpretive understanding. The first order is where people interpret or make sense of the phenomena of the everyday world. The second order of understanding involves generating 'ideal' types from which to interpret or describe the phenomenon being investigated.

It is the intention of the author to use a qualitative approach for analyzing the data, and given the size of the samples, to create an indicative study. This is done by tracking the official Swedish government message to the global publics (in English), based upon the assumption of English being a global lingua franca, and seeing how this message was received and interpreted by international media outlets. For the purposes of achieving this goal, press and public information releases on the Swedish government website (https://www.government.se/) were searched for information concerning the Coronavirus and the government strategy to counter it; there is a specific section on this website that is devoted to the communication of the Swedish government's official position. The aim is to identify and analyze the communicated values of the Swedish government and officials. In order to identify how these narratives and frames were received and interpreted by international media outlets, two particular outlets were selected for analysis: Britain's The Guardian ${ }^{6}$ and The Independent. ${ }^{7}$ These were chosen for several reasons: they are large mainstream news media outlets with a large circulation, and their material is not hidden behind paywalls with readily accessible news archives and are therefore freely accessible.

6 The Guardian appears in tabloid format and positions itself as mainstream journalism with a leftist-liberal editorial bias. Please see https://www. theguardian.com/gnm-archive/2002/jun/06/1 for more.

7 The Independent is much younger and was launched as a quality national newspaper. It positions itself as a non-politically aligned, progressive newspaper with an international outlook. Please see https://www.independent.co.uk/subscribe/our-story for more. 
The material was sought and collected on the Swedish government website and on the websites of the two selected newspapers through manual searches. The search terms on the British newspaper websites used were "Sweden + Coronavirus strategy" (please see further on for results of the search). A period was selected for the material, which starts at the beginning of March 2020 and ends at the end of June 2020. The reasoning behind this is that March represents the month when the pandemic was considered a global crisis and government responses, such as lockdowns and restrictions of travel, began to take shape, and June represents the beginning of the easing of those said restrictions that were intended to counter the spread of the virus and its effects. Furthermore, all of the selected objects of study (Swedish government, The Guardian, and The Independent) are all physically located in the capital cities of their respective countries.

Coding is an essential element in the qualitative research process as it takes apart the data to see what it yields before reconstructing it in a meaningful way (Elliot 2018). There are two broad approaches to coding data: inductive and deductive. The inductive approach uses the data to generate ideas, whereas the deductive method starts with an idea or theoretical framework and uses the data to verify or disprove the idea (Holloway 1997). Schadewitz and Jachna $(2007$, p. 6) note that "often a combination of both approaches is used. A researcher might start with an inductive coding, trying to identify patterns in the data and establish categories by which the remaining data is coded. In further steps, some theoretical constructs can be consulted to explain and evaluate the categories". In order to reach Schutz's (1967) two orders of interpretive understanding, the method of analysis shall employ an inductive data-driven interpretation, as outlined by Boyatzis (1998), to reach the first order. Then a deductive template of codes approach outlined by Crabtree and Miller (1999) will be used to reach the second tier of understanding.

The question is to locate codes that are logical and adequate to the task of interpretation. Therefore, the thematic analysis involves a search for themes that emerge as being important to the description of the phenomenon (Daly et al. 1997). As such, it involves a process of identifying the themes through "careful reading and re-reading of the data" (Rice and Ezzy 1999, p. 258). This was the approach used to identifying the code categories used in this present article: government assistance to Swedish business community and sectors; policy and political statements by the Swedish government; matters pertaining to the budget; measures to ensure public safety; and international joint statements concerning collaboration.

\section{The Swedish Government Message to the World}

Even though Anders Tegnell (State Epidemiologist) was the very high profile global face of the Swedish pandemic response, he was guided and constrained by government thinking and policy on the issue. The official government website, Government Offices of Sweden (https://www.government.se/), is a cyber resource of publicly available information concerning the subjects of the government of Sweden, Swedish government policy, and how Sweden is governed. Informational materials on the official Swedish communications concerning the government's communication of its COVID-19 strategy were sought from this site in the English language (accessible to a wider and more international audience) during the period from 1 March until 30 June 2020. There were a total of 90 hits received, of which 10 were excluded as they were published after 1 July and were therefore outside the timeframe, leaving 80 examples in the sample that were identified and collected for the purpose of analysis. Information that appeared in the section on the official policy response to the Coronavirus had a brief description concerning its purpose.

The Swedish Government has presented a range of different measures to limit the spread of the COVID-19 virus and to mitigate the economic impact of it. The government's overarching goal is to safeguard people's lives and health and to secure the health care capacity. The Government's policy and decisions aim to: Limit the spread of infection in the country; Ensure health care resources are available; Limit the impact on critical services; 
Alleviate the impact on people and companies; Ease concern, for example, by providing information; Ensure that the right measures are taken at the right time.

There is an attempt by the Swedish government, according to Bolsen's (2011) characterization, to shape the political news on the pandemic. The spoken values of concern and importance are public health, but there is also the issue of the economy's health mentioned. There is also an emphasis placed upon the strategy of mitigation, rather than any form of prevention. The aspect of uncertainty that arises during a crisis is addressed by the promise to provide information and ease psychological stress; there is also the acknowledgement of the role of time constraint in the final point, where the stress is placed on correct and timely policy and practical measures. Table 1 gives a monthly breakdown of the number of information releases (in the form of statements, articles, and press releases) each month from March until June and reveals that communications and information posting was more intense at the beginning of the period under analysis.

Table 1. Monthly Communication Activity ${ }^{8}$.

\begin{tabular}{cc}
\hline Month in $\mathbf{2 0 2 0}$ & Number of Posts \\
\hline March & 28 \\
April & 24 \\
May & 11 \\
June & 17 \\
Total: & 80 \\
\hline
\end{tabular}

The topics for the information releases in the month of March varied, and included such topics as official information on budgetary information, travel advisories, economic and financial measures intended to ease negative effects for Swedish companies and businesses, and joint political and policy statements. There was an overwhelming informational focus on government assistance to the Swedish business community and sectors (12), followed by policy and political statements by the Swedish government (six) and then matters pertaining to the budget and measures to ensure public safety (four each), and finally international joint statements concerning collaboration (two). On the March 11th, the government announced a ban on public gatherings and public events. It was not until the March 14th that any uncertainty concerning international travel was officially expressed. This was the point when the World Health Organization declared COVID-19 to be a global pandemic. Travelers were reminded of the rapidly changing travel environment in terms of different countries imposing different rules and restrictive measures, and the necessity to weigh the risks of travelling (in terms of logistics and health risks). Responsibility was placed at the level of the individual. On the same day, the Swedish Ministry of Foreign Affairs advised against all non-essential travel. On March 16th, a politically symbolic statement was released by the Nordic-Baltic Foreign Ministers meeting, stressing the need for co-ordination and cooperation. On March 22nd, the Swedish Prime Minister, Stefan Löfven, addressed the nation, and he emphasized the importance of individual responsibility and reinforced the twin value concerns of public health and economic health. In March, there was an overwhelming emphasis on supporting Swedish businesses and enterprises in terms of financial and other forms of support to mitigate the negative effects of the pandemic, and then to begin the process of recovery of economic activity. Therefore, the political call to action of the crisis centered on the notion of mitigating the financial effects on the Swedish economy

The topics of information posted in April 2020 was more varied than in March: political and policy statements, matters concerning the business sector and economic activity, and issues related to public health were all the most prominent themes (six of each); international statements within the context

8 Found at https://www.government.se/government-policy/the-governments-work-in-response-to-the-virus-responsible-forcovid-19/?page $=1$. 
of different regional and international organizations took second position (four); and budget matters (two) was the least numerous category. There were only four fewer postings than in March, but the value and policy emphasis was markedly different. Human security and the mitigation of the effects on the public became a greater focus, together with the political calls to action and policy measures intended to address various risks and vulnerabilities and to increase resilience through the mitigation of those effects. Some political speeches also displayed the attributes of attempting to promote and export the "Swedish model"; for example, a speech by Lena Hallengren (Minister of Health and Social Affairs) to the WHO:

There has been some interest internationally in our approach to combat the virus. Despite this, I would say that there is no unique Swedish way of dealing with Coronavirus. We do what we think is best based on the development of the pandemic in Sweden and our national circumstances. We are very practical and open to implementing any measures that we think would be effective. But in order to understand our approach, it helps to be aware of some fundamental characteristics of Swedish society. Our welfare state is universal, including the health care system. It is publicly funded and accessible to all. In addressing this situation, we try to build on and utilize established national institutions. There is a tradition of mutual trust between public authorities and citizens. People trust and follow the recommendations of the authorities to a large extent. The Swedish Government has, from the start of the outbreak, applied a 'whole-of-Government' approach. We have presented a range of different measures, both voluntary and legally binding, to limit the spread of COVID-19. Our measures aim to save lives and slow down the outbreak. We've carried out a number of reforms to strengthen our health care system so that our doctors and nurses can cope with the extraordinary challenge that COVID-19 poses (Hallengren 2020).

In this international setting, the Swedish government attempts to frame the value and sanctity of human life being the most important priority, in spite of the empirical evidence so far that speaks against such a stance in practice. As such, it weakens the perception of a united elite consensus on the pandemic response issue as it sends split signals. Although this is not a case of elite disagreement, according to hegemony and indexing theory, it does potentially provide media an opportunity to go beyond the constraints of the political elite debate. An evident tone of an assumed success and superiority in the Swedish model that could be applied by other countries seeking to overcome the effects of the pandemic crisis is discernible. In Mouritzen's (1995) words, it is Sweden trying to "teach" the rest of the world. This is in keeping with Entman's (2004) observation on hegemony that government officials try to keep publicly available (communicated) information within narrow ideological boundaries in order to minimize the deliberation and debate process as a means of attempting to 'force' public consensus. This message to the world is also complemented by other posts that emphasize the need for cooperation and collaboration, such as meetings with the EU and NATO, which was stressed in the Nordic model. This is in keeping with Sundstrom and Elgström's (2019) observation that Sweden seeks to position itself as a norm entrepreneur that seeks to challenge the existing predominant normative frames.

In May, there were only 11 new information posts, and once again there was an observable shift in terms of the rhetorical emphasis on the significant and important values and political and policy priorities. Public safety and health concerns (with a significant focus on the plight of the elderly) was the issue with the most posts (four); political and policy statements, matters concerning the business sector, and economic activity were next with three posts each, and statements within the context of regional and international organizations appeared only once. The clear focus of the crisis communications were now on human security, public health, and public safety. Different vulnerable minorities and groups were identified, as were problematic issues (such as the increase of domestic violence) and how to effectively manage the negative effects on the Swedish economy and business environment (including employees). There was also a shift in focus to some other forms of value threat, namely that of liberalism and the world order as a result of the pandemic. Peter Eriksson, the Minister 
of International Development Cooperation, spoke on these aspects at the Stockholm Forum on Peace and Development.

The free world and open society, as we know it, has partly and temporarily been shut down for many citizens. Factories have had to close as global value chains have been severely interrupted. People have lost their jobs. And politicians with nationalistic agendas have been pointing the finger at 'someone else', in the search for someone to blame when faced with the weaknesses of their own societies. A pandemic will not last forever, but its effects will be felt for years to come. This is a time for reflection on what is fundamentally important to human life. [ ... ] Sweden has a strong commitment through our bilateral and multilateral development cooperation to addressing climate change and biodiversity loss, and to assisting countries in building back greener, more resilient, and more sustainably out of the COVID-19 crisis (Eriksson 2020).

This is another example of an attempt at hegemonic framing by keeping the ideological framework quite narrow and difficult to debate or challenge given the ideological-normative and value virtue signaling. However, rather than attempting to be a "normative entrepreneur", which was the case in March, by promoting the Swedish model, the attempt here is not to change the normative-value based world but to preserve the notions ingrained in the liberal outlook (globalization, multiculturalism, environmentalism, and so forth). Sweden is attempting to not teach the world as in March, but rather to re-join as an active and 'responsible' member of the liberal international order.

The final month to be analyzed was June; 17 new informational items were posted during this time. With Sweden in firm international isolation and under increasing international criticism, another observable shift in official priorities and emphasis in values and norms occurs once more. In the first position of importance by numerical superiority are the themes of political and policy statements, matters concerning the business sector, and economic activity (six each), followed by public safety and health (three) and, lastly, budget (one). The stressed need for international collaboration was repeated by different government ministers, such as the Prime Minister: "Life is not carrying on as normal in Sweden. Sweden has the same goals as all other countries: to save lives and to protect public health. [ ... ] This crisis clearly demonstrates the need to strengthen international collaboration as well as multilateral institutions, to invest in partnerships with civil society as well as in the private sector and to formulate a plan for recovering from this pandemic and coming back stronger and more resilient ahead of the next crises"(Löfven 2020). There was a noticeably more cautious and defensive tone to the communications, such as explanations as to why schools were not closed and measured statements that spoke of a recovery occurring, but warning that the situation was still dangerous. This is an example of what happens when an actor loses any semblance of control of the crisis of information that Joseph Scanlon warned of back in 1975.

This picture of a loss of control and sense of perceived legitimacy has continued beyond the frame of this paper. As a result, the Swedish government's stance, outlined by Coombs (2014), varied from advocacy at the beginning of the period of this study to accommodation by the end of this period, owing to the government's weak position. This weakness has continued; for example, in the unfortunate interview of the Swedish Foreign Minister Anna Linde by Deutsche Welle ${ }^{9}$ or the current advice to Swedish residents and citizens not to make new friends or acquaintances during the summer as a means to stem to the spread of the Coronavirus (The Local 2020). Entman (2004) noted that political maneuvering over news frames is intended to generate support for policy. In the beginning of the study, this is evidently so; the Swedish government is engaging in global advocacy for the Swedish model. However, by the end of this period, it is evident that this has changed to the goal of attempting to reduce international criticism and condemnation of the same Swedish model. How did international

9 To see the interview please see https://www.youtube.com/watch?v=4bCTt3PAPVU. 
media outlets respond to these attempts by the Swedish government to frame their COVID-19 strategy and results favorably?

\section{Mass Media Coverage and Interpretation of the Swedish Message}

Two mass circulation mainstream newspaper outlets in major English speaking countries were chosen: The Guardian (https://www.theguardian.com/uk?INTCMP=CE_UK) and The Independent (https://www.independent.co.uk/), both in the United Kingdom. Various editorials, opinion pieces and news stories on the Swedish Coronavirus strategy were searched for, identified, and collected for the period from March 1st until June 30th, 2020. This was done by using the search function on the websites of the respective media outlets, using the search terms "Sweden" plus "Coronavirus strategy". The initial search hits were then manually checked for relevance, as outlined in the Method and Approach section of this paper. Sixty results were collected from The Guardian and 50 examples formed the sample from The Independent.

\subsection{The Guardian}

A cross section of different articles that are representative of the frames for each month are given. However, this is only a synopsis, given the lack of space for a more full and detailed qualitative account. March is the first month of this analysis, and Sweden was not alone in the world with the 'herd immunity' strategy, which was also, at this stage, part of the UK government strategy before it was subsequently abandoned as being unfeasible. Although admitting some initial concerns, there was an even-handed approach to covering the Swedish government strategy. The argument was that flexibility was needed in countering the virus, given the twin value priorities of public health and health of the economy; it necessitated avoiding mandatory lockdown measures according to the elite consensus at this point (Orange 2020). This was the beginning of the Swedish model frame, especially after the departure of other countries that adopted a similar strategy.

Unlike most EU countries, however-including its Nordic neighbors Denmark, Norway, and Finland-it has not introduced stricter suppression and social distancing orders such as closing bars, restaurants, non-essential shop, and lower schools, nor has it placed citizens in near-total lockdown, as in Italy, Spain, and France. Sweden's chief epidemiologist, Anders Tegnell, has denied the country's approach is to rapidly build group immunity to the virus, a tactic seemingly pursued in Britain and the Netherlands until both recently changed tack after warnings that their health systems could be overwhelmed and death tolls would soar. But Tegnell conceded to the Svenska Dagbladet newspaper last week that such an objective was "not contradictory" with what he described as the government's core strategy, which was to ensure "a slow spread of infection, and that the health services have a reasonable workload" (Henly 2020a).

This situation led to some observers stating that the Swedish government seemed to favor the health of the Swedish economy over public health, which agrees with the data collection from the Swedish Government Offices website for the month of March. There seemed to be a certain level of curiosity with the Swedish model, which gave the official government narrative space in The Guardian, although this was never approaching hegemony as other counter views were also presented to the reader.

April proved to be a month when some signs of support for the Swedish strategy was evident, which was framed within the notion of trust between citizens and the state, where this was a test that was to rely on pre-existing values. "Sweden opted for a calmer-and highly controversial—approach led by the state epidemiologist, Anders Tegnell. Instead of a draconian lockdown, social distancing is a matter of self-regulation. Citizens were instructed to use their judgment and to take individual responsibility within a framework that rested on mutual trust, rather than top-down control. We were both convinced that the "Swedish model" could not be exported to countries such as Spain or Turkey, 
where levels of social and institutional trust are much lower" (Trägårdh and Özkırımlı 2020). Another article appearing in April quoted Tegnell as criticizing the mandatory lockdowns in favor of "civic responsibility" by Swedish citizens, arguing that the more relaxed approach gives greater flexibility in mitigating the pandemic threat (Henly 2020b). This is in line with Nohrstedt's (2011) value based framing as a means to signal societal values within a crisis event. However, notably, the Swedish model is not presented as being something that is universally applicable owing to the differences in culture and value orientation of other countries in terms of variations in national approaches to moral standards towards formal rules and codes of conduct.

In May, the results of the Swedish "experiment" began to be revealed and showed signs of failure as well as some growing sources of domestic and international concern and criticism of the government strategy. In early May, the defense to possible problems emerging in the strategy was that it was simply too early to tell. It was explained that it came to this point through uncritical discussions concerning the perception of Swedish exceptionalism. "It began with a self-conceit that seemed more comical than harmful. Why, one columnist asked, could we not just "let Sweden be Sweden"? Others suggested we brand ourselves "smart Sweden" or "kind Sweden", the country immune to the hysteria of southern Europe" (Gustavsson 2020) However, in spite of mounting evidence, the official Swedish position to the media was that Sweden's laissez faire strategy was the best choice and was superior to the lockdown options imposed by other countries (Henly 2020c). May proved to be a milestone for the downfall of the effectiveness and resonance of the Swedish model frame as the gap between the official frame and the physical results and consequences of the strategy widened.

The coverage of Sweden's Coronavirus strategy in June was one of criticism and rebuke of the Swedish model, where the various flaws were thoroughly identified and scrutinized. Swedish authorities and the government were no longer capable of shaping or influencing the media frame in their favor by keeping information within a narrow ideological framework. The consistency of the message moved decidedly towards a more accommodating posture that was aimed at addressing the growing critique and the realization that they had lost the information crisis. For example, from the June 3rd, an article appeared that was devoted to detailing Anders Tegnell's regrets and admissions of wrongdoing. "Anders Tegnell, who has previously criticized other countries' strict lockdowns as not sustainable in the long run, told Swedish Radio on Wednesday that there was 'quite obviously a potential for improvement in what we have done' in Sweden" (Henly 2020d). Sweden's growing international isolation was detailed in terms of increasingly negative consequences for Sweden and Swedes as a result of the strategy. There were also articles appearing that not only accounted for what had happened, but also for why it had happened.

A commentary by a Swedish journalist in The Guardian announced that the Swedish "experiment" with herd immunity and the Swedish model approach has in effect ended the notion of the reputation and legitimacy of the concept of Swedish exceptionalism. Mentioning that the Opinion Corridor (a process of political and cultural elite consensus that involves a spiral of silence and creates an 'acceptable' orthodoxy of allowable discussion and knowledge) was flawed and wrong, but as there was no room for debate or divergence, there was consequently no escape from the situation. Adding that "at the heart of all this is a national self-image of moral superiority-embodied in the Social Democratic Prime Minister, Stefan Löfven. Despite the horrendous death toll, Löfven still argues his Covid-19 strategy hasn't failed" (Palm 2020) The media index was firmly in a confrontational stance that was not only aimed at countering the elite Swedish political frame, but also at openly challenging its power relations with the Swedish government frame. By this stage, it was the media that was framing the pandemic as a political event by defining the effects and conditions, identifying causes, and conveying moral judgements.

\subsection{The Independent}

The approach to analyzing the material appearing in The Independent was the same as for The Guardian; a representational cross-section of the main frames were given for each month along with 
the same search terms, starting from March. The uniqueness of the Swedish model is explored by the media, whose interest is drawn by the outlier nature of the strategy, but Prime Minister Stefan Löfven has said the responsibility lies with the individual. "We who are adults need to be exactly that: adults. Not spread panic or rumors," he said in a televised address last weekend. "No one is alone in this crisis, but each person has a heavy responsibility." (Habib 2020). These quotes hint at the role and place of the conceptual value-normative basis of Nordicness in the government's media frame. Sweden is framed as being bold and brave in its 'experiment', which is nonetheless not without risk, and Sweden was far from achieving its pariah status by June 2020.

In April, the Swedish government continued to frame the Swedish model as being the correct one and defended it against any criticism. US President Donald Trump claimed that Sweden was suffering due to its refusal to lockdown: "Sweden did that, the herd, they call it the herd. Sweden's suffering very, very badly. It's a way of doing it but the, you know, everybody has been watching everybody else and so far, almost every country has done it the way we've done it, we've chosen to do it". Members of the Swedish government, such as Foreign Minister Anna Linde countered by claiming that Trump was "factually wrong," thereby reinforcing the notion of Swedish exceptionalism (Ng 2020a). The government frame was that Sweden was standing alone in the world with its unique strategy and that this strategy was working (Lovett 2020). Although there is some criticism of the Swedish strategy, which is based upon a variety of contradictory scientific and statistical data, there is a lot of space given to the official framing that is given without interpretation or value judgement added.

The month of May saw a media frame emerge that diverged further from the government frame by highlighting an apparent split in the Swedish elite consensus on the best strategy for mitigating the effects of the Coronavirus. The Prime Minister, Stefan Lövfen, publicly insisted that the Swedish model was the correct one, whereas Anders Tegnell was quoted as being "unconvinced" that the same strategy was the right one (Duncan 2020). One of the media frames was to try and understand the strategy frame from a perspective of domestic Swedish politics. In a similar vein to an article appearing in The Guardian, it was claimed that an underlying reason why there was a lack of public outrage was the presence of a high level of trust between the citizens and the state, which is why this strategy was not universally applicable (Wengstrom 2020). From this point, the opportunities for the Swedish government to influence the media frames on the Swedish model only decreased in an environment of increasing suspicion and isolation.

In the month of June, the pattern in the framing of the Swedish Coronavirus strategy is similar to that seen in The Guardian. There is a great deal of hard criticism of the Swedish model, which is value framed as being the wrong approach, and the cause of the problem is also framed. The first sentence of the article sets the tone: "Sweden has taken the ignominious title of the country with the world's highest death rate from Covid-19" (Cuthbertson 2020) As such, it left little room or ability for the Swedish government to be able to effectively influence the media frame that advocated the Swedish model. Rather, the tone was more accommodating as a means to try and address the criticism; therefore, there was an emphasis on framing the Swedish admission of their 'guilt' in choosing the wrong strategy.

The Swedish government chose to ignore advice from countless health experts to lock the country down and has kept things largely business-as-usual during the pandemic. Primary and secondary schools, restaurants, cafes, and shops remained open and gatherings of up to 50 people were still allowed. [...] But Mr Tegnell said on Wednesday: 'If we would encounter the same disease, with exactly what we know about it today, I think we would land midway between what Sweden did and what the rest of the world did'. Previously, Mr Tegnell has defended Sweden's approach and criticized the lockdowns imposed by other European countries, calling the closing of borders "ridiculous" and "counterproductive" (Ng 2020b)

In addition to the humiliating retreat from advocacy, the Swedish government is forced to shed its exceptionalism frame in favor of a frame that indicates the necessity to join the mainstream norm 
adherent and no longer be a norm entrepreneur. The humanitarian values are severely compromised by the media frame of a negligent, arrogant and 'callous' application of the Swedish model.

\section{Conclusions}

The research questions for this paper are: is it theoretically possible for a foreign government to maintain news frame hegemony in another country's print media during a crisis; and can hegemony or indexing theory of government-state relations can adequately explain and account for the rapid change in the international media framing of the Swedish government's COVID-19 strategy? So, rather than using one or the other theory, both of them were used in order to try and account for the rapid rise and equally rapid fall of the "Swedish model" of COVID-19 strategy. This was done in the hopes of bringing greater explanatory power to interrogating and making sense of the empirical data, which is rather complex and even seemingly contradictory.

It is more usual for hegemony and indexing theory to be applied to cases where the government-media power relations are investigated and analyzed within one country, i.e., a national government and national media (Scollon 2003; Entman 2004; Lemon 2014; Andersen 2017; Allen and Blinder 2018; Kilgo and Harlow 2019; Mulherin and Isakhan 2019). This exploratory study seeks to develop new ground by applying government-media relations that involve a foreign government with media outlets in another country. Of course, such an approach is fraught with various issues and risks, which are mitigated in this instance. The COVID-19 pandemic represents an opportunity for this study because it is a global newsworthy event that attracted a lot of media interest and coverage. Sweden's Coronavirus 'strategy' was more likely to attract international media interest and attention owing to the fact that it represented a clear outlier to the orthodoxy of practice. This represented something new, curious, and newsworthy and was therefore worthy of the news space allocated to it in an attempt to understand it.

Initially, there were two main frames considered at the governmental strategy level: lockdown versus herd immunity. As the lockdown strategy became the hegemonic frame at the expense of herd immunity, mass media frame indexing began to more align with this transformation in the orthodoxy of knowledge. An attempt to market and export the Swedish model, which is based upon the belief of Swedish superiority and exceptionalism, was fraught with the risk of failure from the very beginning. This is based upon the fact and clear signs of dissonance between word and deed that was, at least in part, created by an evident lack of strategic vision that was visualized by the regularly changing value and priority framing by the Swedish government as it reacted to the constantly evolving tactical level environment. The inconsistencies of framing that resulted gave the media much greater leverage and motivation in taking a more critical and independent approach in framing the political news concerning Sweden's Coronavirus strategy or the apparent lack of it. Therefore, both The Guardian and the Independent began with an approach in March that was accommodating to the Swedish government frames owing to the outlier nature that increased a sense of curiosity. By June, the media frames were interpreting and conveying a negative moral judgement and firmly advocating against the Swedish government frames.

Sweden attempted to leverage its relatively popular and positive global brand (before COVID-19) with a value and normative based frame that was intended to enhance the national image of the country and people as capable and courageous norm entrepreneurs by making use of the crisis of information as an opportunity. A hegemony in the frame was not achieved for reasons already stated, and the ability to control or influence the media frame decreased as the distance between the Swedish model and the orthodoxy of approach by other countries using the lockdown strategy increased. The result of this was a political conflict and clash of competing visions and expressions of value and normative symbolism during a global crisis, which tends to see the national level of values and interests trumping the international level, even if, arguably, they belong to the same broader system (Western democracies in the international community, for example). As such, the media frame of Sweden evolved, rather rapidly, from bold to pariah. This article provides an indicative result, and, admittedly, there is more 
research that needs to be done to test this academic problem of understanding government-media relations across international borders in times of crisis.

Theoretically, it is possible for a foreign country to achieve and maintain news frame hegemony; however, it is extremely difficult and contingent upon numerous elements owing to the volatile nature of the politics of crisis management. It depends on the ability of the foreign government's policy line to be in alignment with the government where the media companies in question are based. This creates an alignment of the political elites across borders. As soon as this begins to break and diverge then the chance of hegemony and ability to 'positively' influence news frames is increasingly lost. The Swedish communications were ultimately rejected and criticized as they did not adhere to the orthodoxy of knowledge and practice on the 'best practice' to deal with the COVID-19; it was an outlier case that had different values and practices. However, this was the orthodoxy of knowledge and practice at the time. There is the possibility that this could change and, if it does, the reception of the Swedish COVID-19 management frames may be quite different.

Funding: This article was supported and conducted within the framework of Uppsala University's CIRCUS funding programme within the DigInCom-project.

Acknowledgments: I would like to thank Sia Spiliopoulou Åkermark from the Åland Islands Peace Research Institute for provoking the idea and therefore challenging me to write on this topic through our discussions. A debt of gratitude is owed to the reviewers for their insights and suggestions in helping to better this paper.

Conflicts of Interest: The author declares no conflict of interest.

\section{References}

Aggestam, Karin, and Annika Bergman-Rosamond. 2016. Swedish Feminist Foreign Policy in the Making: Ethics, Politics, and Gender. Ethics \& International Affairs 30: 323-34.

Allen, William, and Scott Blinder. 2018. Media Independence through Routine Press-State Relations: Immigration and Government Statistics in the British Press. The International Journal of Press/Politics 23: 202-26. [CrossRef]

Andersen, Michael Bruun. 2017. Truce and Consequence. Indexing Theory and COP15 in the Danish Press. In Present Scenarios of Media Production and Engagement. Edited by Simone Tosoni, Nico Carpentier, Maria Francesca Murru, Richard Kilborn, Leif Kramp, Risto Kunelius, Anthony McNicholas, Tobias Olsson and Pille Pruulmann-Vengerfeldt. Bremen: Lumiére, pp. 163-72.

Boin, Arjen, Paul t'Hart, Eric Stern, and Bengt Sundelius. 2005. The Politics of Crisis Management: Public Leadership under Pressure. New York: Cambridge University Press.

Bolsen, Toby. 2011. The Construction of News: Energy Crises, Advocacy Messages, and Frames towards Conversation. International Journal of Press/Politics 16: 143-62. [CrossRef]

Boréus, Kristina, and Göran Bergström. 2017. Analysing Text and Discourse: Eight Approaches for the Social Sciences. Thousand Oaks: Sage Publishing.

Boyatzis, Richard. 1998. Transforming Qualitative Information: Thematic Analysis and Code Development. Thousand Oaks: Sage.

Brommesson, Douglas. 2018. Introduction to Special Section: From Nordic Exceptionalism to a Third Order Priority-Variations of "Nordicness" in Foreign and Security Policy. Global Affairs 4: 355-62. [CrossRef]

Brommesson, Douglas. 2018. 'Nordicness' in Swedish Foreign Policy-From Mid Power Internationalisation to Small State Balancing? Global Affairs 4: 391-404. [CrossRef]

Coombs, Timothy. 2014. Applied Crisis Communication and Crisis Management: Cases and Exercises. Thousand Oaks: Sage.

Crabtree, Benjamin, and William Miller. 1999. A Template Approach to Text Analysis: Developing and Using Codebooks. In Doing Qualitative Research. Edited by Benjamin Crabtree and William Miller. Newbury Park: Sage, pp. 163-77.

Cuthbertson, Anthony. 2020. Coronavirus Tracked: Charting Sweden's Disastrous No-Lockdown Strategy. The Independent. Available online: https:/www.independent.co.uk/news/world/europe/coronaviruslockdown-sweden-death-rate-worst-country-covid-19-a9539206.html (accessed on 9 July 2020).

Daly, Jeanne, Allan Kellehear, and Michael Gliksman. 1997. The Public Health Researcher: A Methodological Approach. Melbourne: Oxford University Press. 
Dimitrova, Daniela, and Jesper Strömbäck. 2008. Foreign Policy and the Framing of the 2003 Iraqi War in Elite Swedish and US Newspapers. Media, War \& Conflict 1: 203-20.

Duncan, Conrad. 2020. Sweden's Chief Epidemiologist 'Not Convinced' Country's Relaxed Approach to Coronavirus Is the Right Decision. The Independent. Available online: https://www.independent.co.uk/ news/world/europe/coronavirus-sweden-open-no-lockdown-effects-result-anders-tengell-a9495806.html (accessed on 9 July 2020).

Elliot, Victoria. 2018. Thinking about the Coding Process in Qualitative Data Analysis. The Qualitative Report 23: 2850-61.

Entman, Robert. 2004. Projections of Power: Framing News, Public Opinion, and U.S. Foreign Policy. Chicago: University of Chicago Press.

Eriksson, Peter. 2020. Speech by Minister for International Development Cooperation Peter Eriksson at Stockholm Forum on Peace and Development; Government Offices. Available online: https://www.government.se/speeches/2020/05/speech-by-minister-for-international-developmentcooperation-peter-eriksson-at-stockholm-forum-on-peace-and-development/ (accessed on 8 July 2020).

Fereday, Jennifer, and Eimear Muir-Cochrane. 2006. Demonstrating Rigor Using Thematic Analysis: A Hybrid Approach of Inductive and Deductive Coding and Theme Development. International Journal of Qualitative Methods 5: 80-92. [CrossRef]

Gowing, Nik. 2009. Skyful of Lies' and Black Swans: The New Tyranny of Shifting Information Power in Crises. Oxford: Reuters Institute for the Study of Journalism.

Gustavsson, Gina. 2020. Has Sweden's coronavirus strategy played into the hands of nationalists? The Guardian. Available online: https://www.theguardian.com/world/commentisfree/2020/may/01/sweden-coronavirusstrategy-nationalists-britain (accessed on 8 July 2020).

Habib, Heba. 2020. Sweden Snubs Coronavirus Lockdown with Schools, Restaurants Still Open. The Independent. Available online: https:/www.independent.co.uk/news/world/europe/sweden-coronavirus-lockdownupdate-school-restaurants-a9436241.html (accessed on 9 July 2020).

Hallengren, Lena. 2020. Speech by Minister for Health and Social Affairs Lena Hallengren at WHO Briefing 23 April; Government Offices. Available online: https:/www.government.se/speeches/2020/04/speech-by-ministerfor-health-and-social-affairs-lena-hallengren-at-who-briefing-23-april/ (accessed on 8 July 2020).

Henly, Jon. 2020a. Swedish PM Warned over 'Russian roulette-style' Covid-19 Strategy. The Guardian. Available online: https://www.theguardian.com/world/2020/mar/23/swedish-pm-warned-russian-roulette-covid-19strategy-herd-immunity (accessed on 8 July 2020).

Henly, Jon. 2020b. Sweden Queries Basis of Lockdowns as Germany Keeps Its Guard up. The Guardian. Available online: https://www.theguardian.com/world/2020/apr/24/sweden-queries-basis-of-lockdowns-as-germanykeeps-its-guard-up (accessed on 8 July 2020).

Henly, Jon. 2020c. Just 7.3\% of Stockholm had Covid-19 antibodies by end of April, study shows. The Guardian. Available online: https://www.theguardian.com/world/2020/may/21/just-7-per-cent-of-stockholm-hadcovid-19-antibodies-by-end-of-april-study-sweden-coronavirus (accessed on 8 July 2020).

Henly, Jon. 2020d. We Should Have Done More, Admits Architect of Sweden's Covid-19 Strategy. The Guardian. Available online: https:/www.theguardian.com/world/2020/jun/03/architect-of-swedencoronavirus-strategy-admits-too-many-died-anders-tegnell (accessed on 8 July 2020).

Holloway, Immy. 1997. Basic Concepts for Qualitative Research. Oxford: Blackwell Science.

IMF. 2020. International Monetary Fund's Policy Tracker. Available online: https:/www.imf.org/en/Topics/imfand-covid19/Policy-Responses-to-COVID-19 (accessed on 7 July 2020).

Kilgo, Danielle, and Summer Harlow. 2019. Protests, Media Coverage, and a Hierarchy of Social Struggle. The International Journal of Press/Politics 24: 508-30. [CrossRef]

Lemon, Edward. 2014. Mediating the Conflict in the Rasht Valley, Tajikistan. Central Asian Affairs 1: $247-72$. [CrossRef]

Lovett, Samuel. 2020. Coronavirus: Scientist Leading Sweden's COVID-19 Response Says UK Lockdown has Gone too far. The Independent. Available online: https://www.independent.co.uk/news/health/coronavirusuk-lockdown-sweden-scientist-response-gone-too-far-a9448026.html (accessed on 9 July 2020).

Ludwigsson, Jonas. 2020. The First Eight Months of Sweden's COVID-19 Strategy and the Key Actions and Actors that Were Involved. Acta Paediatrica: Nurturing the Child 1-13. [CrossRef] 
Löfven, Stefan. 2020. Prime Minister Stefan Löfven on International Collaboration to Handle COVID-19; Government. Available online: https://www.government.se/articles/2020/06/prime-minister-stefan-lofvenon-international-collaboration-to-handle-covid-19/ (accessed on 8 July 2020).

Mouritzen, Hans. 1995. The Nordic Model as a Foreign Policy Instrument: Its Rise and Fall. Journal of Peace Research 32: 9-21. [CrossRef]

Mulherin, Peter, and Benjamin Isakhan. 2019. State-Media Consensus on Going to War? Australian Newspapers, Political Elites, and Fighting the Islamic State. The International Journal of Press/Politics 24: 531-50. [CrossRef]

$\mathrm{Ng}$, Kate. 2020a. Coronavirus: Sweden Rejects Trump's Claim Country is 'Suffering' Due to its Refusal to Lockdown. The Independent. Available online: https://www.independent.co.uk/news/world/europe/coronavirus-swedentrump-lockdown-herd-wrong-a9459111.html (accessed on 9 July 2020).

$\mathrm{Ng}$, Kate. 2020b. Coronavirus: Sweden admits it would have done More to Lock Down 'if we Knew What we Know Today. The Independent. Available online: https://www.independent.co.uk/news/world/europe/ coronavirus-sweden-lockdown-cases-anders-tegnell-deaths-a9545746.html (accessed on 9 July 2020).

Nohrstedt, Daniel. 2011. Uncertainty, Accountability, and the Conduct of Post-Crisis Inquiries. In Ethics and Crisis Management. Edited by L. Svedin. Charlotte: Information Age Publishing.

OECD. 2020. The Territorial Impact of COVID-19: Managing the Crisis across Levels of Government. Available online: https://www.oecd.org/coronavirus/policy-responses/the-territorial-impact-of-covid-19-managingthe-crisis-across-levels-of-government-d3e314e1/ (accessed on 7 July 2020).

Ogrizek, Michel, and Jean-Michel Guillery. 1999. Communicating in Crisis: A Theoretical and Practical Guide to Crisis Management. New York: Aldine De Gruyter.

Orange, Richard. 2020. As the Rest of Europe Lives under Lockdown, Sweden Keeps Calm and Carries on. The Guardian. Available online: https://www.theguardian.com/world/2020/mar/28/as-the-rest-of-europelives-under-lockdown-sweden-keeps-calm-and-carries-on (accessed on 8 July 2020).

Palm, Erik Augustin. 2020. Swedish Exceptionalism Has Been Ended by Coronavirus. The Guardian. Available online: https://www.theguardian.com/commentisfree/2020/jun/26/swedish-exceptionalism-coronaviruscovid19-death-toll (accessed on 8 July 2020).

Porfiriev, Boris, and Greg Simons, eds. 2012. Crises in Russia: Contemporary Management Policy and Practice from A Historical Perspective. Farnham: Ashgate.

Rice, Pranee Liamputtong, and Douglas Ezzy. 1999. Qualitative Research Methods: A Health Focu. Melbourne: Oxford University Press.

Rodelo, Frida, and Carlos Muniz. 2019. Government Frames and Their Influence on News Framing: An Analysis of Cross-Lagged Correlations in the Mexican Context. Global Media and Communication 15: 103-19. [CrossRef]

Savage, Maddy. 2020. Did Sweden's Coronavirus Strategy Succeed or Fail? BBC News. Available online: https://www.bbc.com/news/world-europe-53498133 (accessed on 27 October 2020).

Schadewitz, Nicole, and Timothy Jachna. 2007. Comparing Inductive and Deductive Methodologies for Design Patterns Identification and Articulation. Paper presented at International Design Research Conference IADSR 2007 Emerging Trends in Design Research, Hong Kong, China, November 12-15.

Schutz, Alfred. 1967. The Phenomenology of the Social World. Translated by George Walsh, and Fredrick Lehnert. Evanston: North Western University Press.

Scollon, Suzanne. 2003. Body Idiom in Platform Events: Media Representation and the Hegemony of the Vicarious Conversation. Social Semiotics 13: 89-102. [CrossRef]

Sevin, Efe. 2017. Public Diplomacy and the Implementation of Foreign Policy in the US, Sweden and Turkey. Cham: Palgrave MacMillan.

Simons, Greg, and Andrey Manoilo. 2019. Sweden's Self-Perceived Global Role: Promises and Contradictions. Research in Globalization 1.

Simons, Greg, Andrey Manoilo, and Philip Trunov. 2019. Sweden and the NATO Debate: Views from Sweden and Russia. Global Affairs 5: 335-45. [CrossRef]

Simons, Greg, and Marina Kukartseva. 2019. New Cold War and the Crisis of the Liberal Global Order. Outlines of Global Transformations: Politics, Economics, Law 12: 77-93. [CrossRef]

Sundstrom, Malena Rosén, and Ole Elgström. 2019. Praise or Critique? Sweden's Feminist Foreign Policy in the Eyes of its Fellow EU Members. European Politics and Society. [CrossRef] 
The Local. 2020. 'Don't Meet New People This Summer': Sweden's Latest Warning to Residents. The Local. Available online: https:/www.thelocal.se/20200708/dont-meet-new-people-this-summer-sweden-warnspeople-to-keep-following-coronavirus-guidelines (accessed on 8 July 2020).

Trägårdh, Lars, and Umut Özkırımlı. 2020. Why might Sweden's Covid-19 policy work? Trust between Citizens and State. The Guardian. Available online: https://www.theguardian.com/world/commentisfree/2020/apr/21/ sweden-covid-19-policy-trust-citizens-state (accessed on 8 July 2020).

Wengstrom, Erik. 2020. 'Only the Best Intentions': What do Swedish People Really Think of Their Relaxed Coronavirus Approach? The Independent. Available online: https://www.independent.co.uk/ news/coronavirus-what-sweden-thinks-lockdown-relaxed-a9492361.html (accessed on 9 July 2020).

Publisher's Note: MDPI stays neutral with regard to jurisdictional claims in published maps and institutional affiliations.

(C) 2020 by the author. Licensee MDPI, Basel, Switzerland. This article is an open access article distributed under the terms and conditions of the Creative Commons Attribution (CC BY) license (http://creativecommons.org/licenses/by/4.0/). 